\title{
Jacka Filka fenomenologiczne rozważania wokół kwestii wychowania
}

\section{Wprowadzenie}

Rodzinę można próbować scharakteryzować przez pryzmat pełnionych przez nią funkcji, a jedną z kluczowych jest wychowywanie, któremu sprzyja przestrzeń domu rodzinnego. Rodzice jako pierwsi nauczyciele odsłaniają przed dzieckiem doświadczenia spotkania i dialogu, a samo wychowanie odbywa się w przestrzeni wartości konstytuujących tożsamość człowieka. To w nim dopełniają się macierzyństwo i ojcostwo. Pedagog przyjmuje na siebie odpowiedzialność, nie pozostawiając wychowanka samemu sobie. Prawda o wychowawcy ujawnia się w jego nieprzerwanej pracy nad samym sobą. Przykład trudu, jakiego podejmuje się w tej pracy, pociąga wychowanka do autentycznego zaangażowania we własny rozwój.

Wychowanie jest więc ubogaceniem wnętrza człowieka w spotkaniu z dorosłym. „Autentyczność, a zarazem skuteczność świadectwa wychowawcy - pisze Paweł Walczak z Uniwersytetu Zielonogórskiego - wypływa 
z jego czystej intencji, gdy trud świadczenia o dobru podjęty jest z prawdziwego uznania wartości, nie zaś na pokaz dla odgrywania roli wychowawcy. Wychowawca musi być sobą i swoją prawdę odsłaniać przed wychowankiem"1. Wychowawca aksjologicznie nijaki nie potrafi zaproponować treści, w których wychowanek mógłby odkryć sens i które mogłyby ukazać przed nim etos wychowania.

Jarosław Gara - autor, który na gruncie nauk pedagogicznych oraz filozofii wychowania korzysta z dorobku filozofii dialogu i fenomenologii przekonuje, że wychowanie i wartości wzajemnie się determinują: wartości wyznaczają tożsamość wychowaniu, zaś wychowanie je wdraża i realizuje. Samo wychowanie staje się wartością, gdy przenika je określony logos. To, co będzie treścią owego procesu, ukierunkuje działalność pedagogiczną. Wyłaniające się z niej wartości stanowią sens życia rodzinnego i są cenne dla rodziny. Gara tłumaczy, że kwestię wychowania należy rozważać poprzez ustalenie tego, „W jaki sposób i w oparciu o jakie wartości (rozstrzygnięcia natury aksjologicznej) inicjować konstruktywne formy wywierania wpływu na drugiego człowieka i czemu powinny one służyć (rozstrzygnięcia natury teleologicznej)"2. Fundamentalną kwestią pozostaje pytanie o naturę człowieka, o jej potencjalność i możność aktualizowania się w człowieczeństwie poprzez wychowanie.

\subsection{Definicje wychowania}

Tego, co kryje się pod hasłem „wychowanie”, nie sposób zawrzeć w jednej definicji. W opisie tego pojęcia będzie się krył cały szereg działań. Warto podejmować próby odseparowania pojęcia od jego dookreśleń, jakimi są np. teoria wartości czy nurtów pedagogicznych. Historycznie wychowanie podlegało rozmaitym przeobrażeniom, a na przestrzeni ostatnich kilkudziesięciu lat nastąpiły gwałtowne zmiany w jego postrzeganiu i realizowaniu. Ewolucja ta widoczna jest w sferze dziecięcej rzeczywistości. Pojawiły się takie zjawiska

1 P. Walczak, Wychowanie jako spotkanie. Józefa Tischnera filozofia człowieka jako źródło inspiracji pedagogicznych, Kraków 2009, s. 166. Por. B. Skarga, Kwintet metafizyczny, Kraków 2005, s. 119-120; W. Cichosz, Czytelność aksjologiczna nauczyciela-wychowawcy, „Studia Gdańskie” 18-19 (2005-2006), s. 157-161.

2 J. Gara, Od filozoficznych podstaw wychowania do ejdetycznej filozofii wychowania, Warszawa 2009, s. 110. 
jak tzw. pokolenie z kluczem na szyi, cyberdziecko - od pierwszych miesięcy stymulowane smartfonem, tabletem, a w kolejnych latach życia przebodźcowane technologią internetową. Relacja matki z dzieckiem została zaś podporządkowana różnym koncepcjom wychowawczym (widać tu wpływ poradników i programów moralizujących na matki). Równolegle do zmian gospodarczych, które wpływały na całe rodziny, także w systemie edukacyjnym następowały przeobrażenia w podejściu do wychowania. Wiązało się to oczywiście z pojawieniem się nowych sposobów kształcenia nauczycieli i licznymi działaniami przekształcającymi program edukacyjny.

Adam Maj definiuje wychowanie jako: „całokształt oddziaływań na osobowość wychowanka (zmienianie jej, formowanie) i procesów zachodzących w trakcie międzyosobowej relacji z wychowawcą, wspierający rozwój człowieczeństwa dziecka oraz efekt tych oddziaływań i procesów (... $)^{3}$. Proponowaną definicję można próbować usystematyzować w nurcie aksjologii rodziny. To właśnie ten kierunek skłania do zrozumienia wartości wychowania rozumianego nie jako zadanie, ale powołanie.

Jan Galarowicz - krakowski myśliciel specjalizujący się w filozofii człowieka - przekonuje, że to dom jest najbardziej naturalnym miejscem wychowania człowieka, a instytucje takie jak szkoła uzupełniają działania rodziców i ich wpierają. Badacz wskazuje na środowisko rodzinne, w którym wychowywanie jest inicjowane. Dom jest pierwszą przestrzenią wychowawczą, która oddziałuje zarówno na wychowawcę, jak i na wychowanka. Jeśli rodzic $\mathrm{z}$ jakichś powodów nie jest w stanie realizować wychowania, wówczas instytucje będą pełniły funkcję wzmacniającą.

Konstytucja Rzeczypospolitej Polskiej przyznaje rodzicom „prawo do wychowywania dzieci zgodnie z własnymi przekonaniami. Wychowanie to powinno uwzględniać stopień dojrzałości dziecka, a także wolność jego sumienia i wyznania oraz jego przekonania"4. Ważny jest tu aspekt wychowania jako prawa, a nie jako obowiązku. Takie ujęcie daje rodzicom możliwość skorzystania z przyznanych im praw, nie stawia jednak przed nimi żadnych konkretnych zadań. Można zatem sądzić, że wychowanie nie jest obowiązkiem wypływającym $\mathrm{z}$ rodzicielstwa, ale moralnym przywilejem każdego $\mathrm{z}$ rodziców.

3 Wychowanie, w: Encyklopedia aksjologii pedagogicznej, red. K. Chałas, A. Maj, Radom 2016, s. 1368.

$4 \quad$ Konstytucja Rzeczypospolitej Polskiej z dnia 2 kwietnia 1997 r., Art. 48, pkt. 1. 
Jeszcze inny kierunek myślenia o wychowaniu propagował Józef Tischner - ksiądz-filozof. Jego zdaniem zdolni do podjęcia tego zadania są tylko ci, którzy żywią nadzieję, a zatem sam ten proces będzie pracą według nadziei. Cnota ta uzdalnia niejako wychowawcę do pracy z wychowankiem. Według Tischnera centralną zasadą wychowania jest dochowanie wierności wychowankowi. Twórca filozofii dramatu postuluje: „Tutaj nie wolno zdradzać - nie wolno pod żadnym pozorem. Więzów powiernictwa nadziei zrywać nie wolno" 5 . Wychowawca rozbudza w wychowanku nadzieje, chce pokazać mu świat po to, żeby ten mógł go odkrywać.

\subsection{Istota wychowania}

Współczesne poszukiwania odpowiedzi na pytanie: „czym jest wychowanie?” zmierzają do określenia jego istoty w praktyce codzienności. Jacek Filek wyraża się o powszechnie dyskutowanym kryzysie wychowania jako o problemie praktycznym. Dostrzega pewne braki w teorii pedagogicznej, u której podstaw należałoby rozpocząć porządkowanie tego procesu. Pisze: „Trzeba tak rozbudować teorię, by rozświetliła ona mroki praktyki, by jaśniej i wyraźniej ukazała całą przestrzeń pseudowychowania”6. Odpowiedzialność wychowawcy polega na podejmowaniu wysiłku myślenia, dzięki któremu można na nowo spojrzeć na kwestię wychowania. Filek zapytuje o istotę aktu wychowania, a więc analizuje ów fenomen poprzez uchwycenie zależności, które przybliżają do ogólnego rozumienia tego procesu. W takim rozumieniu nie są istotne cele wychowawcze. Nieograniczanie definicji wychowania do pełnionych przez nie funkcji docieka jego istoty.

\section{Doświadczenie wychowania}

Wychowanie wydarza się w przestrzeni dialogicznej, międzypodmiotowej. Zaakcentowanie podmiotowości jest istotne, ponieważ czym innym jest wychowanie psa, a czym innym dziecka. Człowiek jako istota posiadająca

5 J. Tischner, Alfabet duszy i ciała, Kraków 2018, s. 229.

6 J. Filek, Filozofia jako etyka. Eseje filozoficzno-etyczne, Kraków 2001, s. 82. 
własną podmiotowość jest $\mathrm{z}$ natury zdolny do wychowywania i bycia wychowywanym. Należy zatem przyjąć, że proces ten przebiega pomiędzy ludźmi, wydarza się w przestrzeni podmiotów. Znane są przypadki dorastania człowieka w zwierzęcym środowisku, ale nie mają one nic wspólnego z wychowaniem. Przeciwnie - potwierdzają one, że aby wychowanie mogło się wydarzyć, zawsze musi być spotkaniem w przestrzeni międzyosobowej. Jarosław Gara przekonuje, że rozwój jest procesem dorastania do własnego człowieczeństwa. Pisze: „dziecko nie jest od razu, czy też w ogóle nie jest, wszystkim tym, czym w przyszłości może być. Najważniejsze zatem jest, (...) kim się staje i czy w ogóle się staje, do czego odnosi swoje życie i co jest miarą ocenną tego, co słuszne i wartościowe"7. Drugi człowiek może zachęcać wychowanka, aby podejmował działanie, jednak by ten przejął się swoim wychowaniem, niezbędna jest jego wola. To ona uzdalnia go do samowychowania.

$\mathrm{Z}$ jednej strony więc wychowania doświadcza wychowawca, z drugiej wychowanek. Późniejsze rozważania dopiero potwierdzą tezę, że wychowanek także oddziałuje na wychowawcę. Oba te podmioty uczestniczą w tym samym procesie, choć dla każdego $\mathrm{z}$ nich będzie on miał inne znaczenie. Doświadczenie to mieści się w logice przywoływanego przez Filka „działania-doznawania”, które pozostawia w człowieku ślad i różnicuje jakościowo jego wybory życiowe. Można zatem założyć, że pod wpływem wychowania następuje w człowieku pewna zmiana, początkowo naznaczona niewiadomą, nieznane bowiem pozostaje oddziaływanie wychowawcze.

$\mathrm{Na}$ kształt wychowania wpływają warunki, w jakich się ono odbywa. Otoczenie wraz z jego interakcjami sąsiedzkimi, przestrzenie znaczące (znajome miejsca i okolice), tradycje lokalne i narodowościowe składają się na szersze oddziaływanie wychowawcze - nie zawsze dopasowane do danego człowieka, niekiedy nawet przypadkowe. W węższym znaczeniu o oddziaływaniu wychowawczym można mówić wówczas, gdy wychowawca podejmuje wobec wychowanka pewne zamierzone działania. Takie oddziaływanie charakteryzuje się dwubiegunowością, gdyż angażuje oba podmioty, a ponieważ jest ono zwrócone w stronę konkretnej osoby, nie rozmywa się w okolicznościach zewnętrznych i wychowanek może je przyswoić. Ta świadomość doznawania wychowującego wywiera wpływ także na działanie

7 J. Gara, Człowiek $i$ wychowanie. Implikacje pedagogiczne antropologii filozoficznej Maxa Schelera oraz analogie $z$ wybranymi koncepcjami psychologicznymi, Warszawa 2007, s. 113. 
wychowawcy, który winien ten proces uskuteczniać, wykorzystując różne możliwości oddziaływania.

\subsection{Postawy wobec wychowania}

Jacek Filek zauważa potrzebę znajomości okoliczności zewnętrznych w podejmowanych działaniach wychowawczych. Jest jednak przekonany, że wychowanek musi się im niekiedy przeciwstawić, by móc rozpoznać swój potencjał i podjąć trud samorozwoju. Starania, które dorosły kieruje wobec wychowanka, są świadome i możliwe do realizacji. Młody człowiek staje wobec wyboru: podjąć aktywność, nawiązać dialog, a nawet wyrazić swój bunt, lub pozostać biernym podmiotem wychowania. Jego pasywność utrudnia działalność wychowawczą, ale bunt - jako hiperaktywność - także stanowi wyzwanie dla wychowawcy. W jego przypadku wychowanek poprzez niezgodę na zastane okoliczności nawiązuje jednak dialog.

Trudno jednoznacznie oddzielić wychowanie z punktu widzenia wychowawcy od perspektywy wychowanka - proces ten wydaje się bardziej współdziałaniem obu podmiotów. Filek jest zdania, że wychowanie jako działanie i wychowanie jako doznawanie wzajemnie się przenikają. Wychowanie zawsze jest „współdziałaniem” - a ono z kolei warunkuje wychowanie. O „współdoznawaniu” stanowi zaś doświadczenie podmiotowości wychowanka, które jest ważnym punktem rozważań o relacyjności wychowania. Wychowawca i wychowanek potrzebują siebie nawzajem. Według Filka człowiek nie byłby sobą bez odniesienia do drugiego człowieka. Ścieranie się tych dwóch podmiotów na drodze wychowania rodzi napięcie, przybiera postać walki o wolność, o uznanie, co wskazuje na konieczność współdziałania na rzecz wychowania. Dopiero gdy podmioty wychowania zanegują siebie same i zaprzeczą istnieniu bez siebie nawzajem, pozór zostanie zdemaskowany i rozpocznie się proces poszukiwania i potwierdzania tożsamości wychowawczej ich obojga „w działaniu i doznawaniu”. Takie dialektyczne sprzężenie podmiotów wychowania jest ograniczone wolą czynienia dobra dla wychowanka.

Jarosław Gara twierdzi, że w życie człowieka wpisana jest potrzeba wychowania. Autor pisze o tym w taki sposób: „Samo wychowanie wypływa

8 J. Filek, Filozofia jako etyka. Eseje filozoficzno-etyczne, dz. cyt., s. 82. 
więc z konieczności, która wpisana jest w strukturę ludzkiego życia, człowiek jako człowiek potrzebuje bowiem wychowania. Bez wychowania nie ma możliwości wydobycia potencji rozwojowych tkwiących w jednostce oraz zoptymalizowania ich wykorzystania przez nią w przyrodniczym

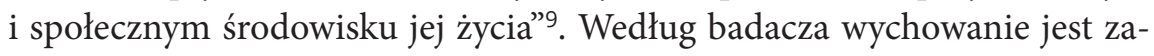
tem wkomponowane w ludzkie życie, a człowiek nie rozwija się przez przypadek. Działalność wychowawcza ma za zadanie wyłonić i ukierunkować potencjał rozwojowy wychowanka.

\subsection{Oddziaływanie wychowawców}

Analiza modelu trójargumentowej relacji wychowawczej (skonstruowanej przez Filka na podstawie etymologii greckiego paidagogos) zwraca na siebie uwagę pośrednim podmiotem działania. Dotychczas zostało powiedziane, że młody człowiek otrzymuje wychowanie na skutek działania wychowawcy. W opisywanym modelu podmiot bezpośredni powierza wychowanka podmiotowi pośredniemu, nie przestając jednak być także jego wychowawcą. Zmienia się jego rola $\mathrm{z}$ podmiotu bezpośrednio podejmującego działanie na kontrolującego działanie. Taką sytuację można rozpoznać w przypadku pozostawiania dzieci w instytucjach oświatowych lub pod opieką niań czy guwernantek. Rodzic niejako zleca wychowanie komuś innemu na zasadzie umowy przekazującej wychowanie. Młody człowiek otrzyma więc wychowanie, chociaż pozostanie ono oddziaływaniem podmiotowym, dialog będzie przebiegał już z całą pewnością inaczej. Podmiotowi pośredniemu, czyli przykładowej opiekunce, która aranżuje wprawdzie okoliczności wychowawcze, trudno jednak przyznać podejmowanie bezpośredniej akcji wychowawczej. Działalność wychowawcza, która nie wypływa z faktu bycia wychowawcą bezpośrednim, a często nawet mija się z powołaniem do wychowania innych, pozostanie zaledwie pracą zarobkową. Nie ma nic wspólnego $\mathrm{z}$ wychowaniem pojmowanym jako pomoc w narodzinach człowieka ${ }^{10}$.

9 J. Gara, Od filozoficznych podstaw wychowania do ejdetycznej filozofii wychowania, dz. cyt., s. 248.

10 Zob. J. Tischner, Droga Sokratesa i perć Sabały, www.tischner.pl/aktualnosc/1365/1/ ks-jozef-tischner-droga-sokratesa-i-perc-sabaly (15.11.2016). 
Niekwestionowane wsparcie pierwszych wychowawców stanowi system edukacji, mało tego - niekiedy nawet przejmuje on za nich zadania wychowawcze. Instytucje oświatowe są powołane główne do pełnienia funkcji opiekuńczej i edukacyjnej. Podmioty pośrednie, jak np. nauczyciele, dopiero jako zwierzchnicy wychowywania będą podejmowali się pedagogicznego oddziaływania. Według Jacka Filka ten rodzaj działania pozostaje jednak w obrębie innej niż wychowanie aktywności, noszącej już znamiona pseudowychowania. Faktem jest, że współczesna rodzina posługuje się na ogół podmiotem pośrednim wychowania, co nie musi mieć bezpośredniego związku z wychowaniem. Z drugiej strony można zaobserwować wzrost świadomości w zakresie wychowania, o czym świadczy wyższy procent rodziców decydujących się na edukację domową ${ }^{11}$, tworzących przedszkola i szkoły rodzinne ${ }^{12}$, m.in. właśnie po to, aby móc bezpośrednio pełnić funkcję zaangażowanego podmiotu wychowania.

Skoro wiadomo już, że wychowawca w dwojaki sposób oddziałuje na wychowanka, ten będzie otrzymywał wychowanie podwójnym tego słowa znaczeniu: w sposób bezpośredni i pośredni. Jak tłumaczy Filek, wychowawcy została przydana możność wychowania „komuś” lub „czemuś”. Różnica pomiędzy podmiotem wychowywanym pośrednio a tym wychowywanym bezpośrednio ukazuje ów najbardziej właściwy akt wychowawczy. Uczony pisze: „wychowanie jest uniwersalne, absolutnie rozwijające, wolne od partykularyzmów, od zniewalającego zewnętrznego przymusu. Samo siebie inicjuje, samo sobą rządzi i samo siebie kontroluje"13. Filek zwraca uwagę na wspólny wysiłek podmiotów wychowujących będący wyrazem jedności i troski o wychowanie.

Takiej koncepcji zostaje przeciwstawione wychowanie jednostkowe, fragmentaryczne. Niekompletne podejście do wychowania niesie według badacza zagrożenie wychowania człowieka w sposób cząstkowy. Wyrywkowe, choć bezpośrednie działanie podmiotu wychowującego, nie może izolować się od okoliczności zewnętrznych, czyli tych wszystkich społecznych,

11 Por. Kondycja edukacji domowej w Polsce, www.edukacjadomowa.pl/kondycjaedukacji-domowej-w-polsce/ (23.07.2018).

12 Por. M. Kapias, Szkoła rodzinna jako alternatywna kategoria wychowawcza, w: Opieka jako kategoria wychowawcza. Metody i formy stymulowania dzieci i młodzieży $w$ rodzinie $i$ środowisku lokalnym, red. U. Gruca-Miąsik, Rzeszów 2016, s. 62-69.

13 J. Filek, Filozofia jako etyka. Eseje filozoficzno-etyczne, dz. cyt., s. 97. 
kulturowych, religijnych, politycznych i innych jeszcze czynników, które owe okoliczności wychowawcze tworzą, oddziałując na wychowanie.

\section{Teoria pseudowychowania}

Dostrzeżone braki definicyjne skutkują nieprecyzyjnym, a nawet nietrafnym opisem fenomenu wychowania. Trudno przedstawiać rzeczywistość bez odpowiednio skonstruowanych pojęć. Stąd według Jacka Filka niekiedy łatwiej opisywać dany fenomen, posługując się metodą przeciwieństw. Poszukiwanie odpowiedzi na pytanie o to, czym wychowanie jest, może się zatem odbywać poprzez ustalenie, czym ono z pewnością nie jest $\mathrm{t}^{14}$. Filek twierdzi, że wychowanie nie jest ani chałturzeniem, ani hochsztaplerką, ani udawaną troską. Swoje przekonanie potwierdza, obnażając teorię pseudowychowania. Ta kategoria trafnie uwydatnia to, co jest różne od wychowania, co skrywa się w jego pozorze i uzurpuje sobie prawo do samostanowienia o sobie. Łatwo dostrzec, że pseudowychowanie najpierw zawłaszcza sobie terminologię, ukrywa się pod nomenklaturą wychowania, nie będąc nim jednak. Co zatem skrywa? Ku czemu zmierza? Można pomyśleć, że falsyfikuje działalność wychowawczą, zmierzając tą samą drogą, a jednocześnie w innym niż wychowanie kierunku. Pseudowychowanie jest groźne przede wszystkim dlatego, że stopuje wychowanie, ogranicza je, uniemożliwia. Postępowe działanie przeciwko samemu wychowaniu może być w pewnym sensie kojarzone z przemocą. Jeśli z uporem ogranicza się wpływ

14 Por. J. Gara, Od filozoficznych podstaw wychowania do ejdetycznej filozofii wychowania, dz. cyt., s. 252. Gara wyraża swoją wątpliwość wobec takiego podejścia. Zastanawia się, czy badanie tego, co jest negatywne, może być trafne bez wcześniejszego osądu co do tego, co jest pozytywne. Taka bezzałożeniowość wydaje się autorowi niemożliwa bez pewnych przeczuć w kwestii rozeznania, czym wychowanie właściwie jest. Trudno odmówić Filkowi słusznych intuicji, autor bowiem skupia się w swoich rozważaniach na fenomenologicznej analizie wychowania. Zajmuje się więc badaniem tego, co stanowi reprezentację fenomenu. Jeśli więc pseudowychowanie jest kategorią daną bezpośrednio, trudno zająć się opisem rzeczywistości innej niż ta, jaką ona się jawi. Por. J. Tischner, Filozofia dramatu. Wprowadzenie, Kraków 2001, s. 301. Także Tischner jest przekonany, „iż dobro jest wprawdzie bliższe naszym nadziejom, ale zło jest jednak bliższe naszym doświadczeniom. Filozofia, która przyznaje się do stosowania metody fenomenologicznej, jest niejako z góry skazana na przyznanie pierwszeństwa badaniom zła przed badaniami dobra”. 
właściwego wychowania, to de facto wykorzenia się człowieka z jego natury. Pseudowychowanie fałszuje rzeczywistość wychowawczą, dlatego zaangażowane podmioty w zasadzie przez cały czas trwania procesu wychowawczego starają się strzec przed pseudowychowaniem. Brak standaryzacji wychowania sprawia jednak, że często nie udaje się zawczasu zdemaskować jego imitacji. Właśnie dlatego tak ważne jest skonkretyzowanie kategorii wychowania - wszelkie jego definicje przeciwstawią się pseudowychowaniu, a wiec będą określały, czym nie jest samo wychowanie.

\subsection{Formy pseudowychowania}

Jako jeden z przykładów pseudowychowania Jacek Filek wymienia wychowanie nieadekwatne. Doświadczenie wychowania może rodzić w każdym z podmiotów wątpliwości co do jego akuratności. Ta odmienna perspektywa pedagogiczna będzie skutkowała różnorodnymi próbami aktywności wychowawczej. Adekwatność wychowania ma miejsce wtedy, kiedy podejmowana aktywność dowodzi relacyjności oddziaływania między podmiotami. Innymi słowy - wychowanie jest nieadekwatne, gdy mija się z rzeczywistymi potrzebami człowieka. Ich tępienie, forsowanie innych działań zamiast tych, które są w stanie je zaspokoić, stanowią manipulację, a wprowadzane pod groźbą nie-doznawania stanowią przemoc. Niestety zwykle takie działania są programowe i szeroki mają zasięg.

W wąskim znaczeniu wychowanie nieadekwatne jest działaniem bez planu, przypadkowym, budującym nie na potencjale wychowanka, ale wbrew niemu. Tymczasem wychowanie powinno mierzyć się z rzeczywistością, rozeznawać kontekst historyczny po to, aby we właściwy sposób odpowiadać wymaganiom teraźniejszości. Czym byłby ów proces, jeśli rugowano by pamięć o przeszłości? Wychowanie adekwatne obejmuje więc swoim zasięgiem całościową troskę podmiotu wychowującego o człowieka, zarówno w sytuacji ogólnej, jak i szczególnej. Jego adekwatność ujawnia się we właściwym rozpoznaniu własnych możliwości w połączeniu $\mathrm{z}$ troską o drugą osobę.

Rodzajem pseudowychowania, które według Filka oddziela działanie od doznawania, jest także „wychowanie fikcyjne”. Jak już zaznaczono, wychowawca i wychowanek oddziałują na siebie wzajemnie. Brak jedności w ich współdziałaniu będzie skutkował wychowaniem cząstkowym. Wykluczenie, 
choćby w jakiejś tylko mierze, pola działania lub doznawania przekreśla całokształt wychowania. O wychowaniu fikcyjnym mówimy wówczas, gdy działanie jest pozorne. Dzieje się tak, gdy podmiot wie, że nie odzwierciedla się ono w doznawaniu, ale podmioty tworzą i zachowują iluzję wychowawczą. Fikcyjna działalność wychowawcza wskazuje także na brak jedności podmiotów $\mathrm{i}$ jest $\mathrm{z}$ pewnością fiaskiem wychowawczym.

Kolejną odsłoną pseudowychowania jest wychowanie wyobcowane. Działalność wychowawcza jest bowiem prawdziwa, kiedy wychowawca identyfikuje się z celem wychowawczym. Gdy dzieje się inaczej i podmiot nie utożsamia się z działalnością, jej owoc jest dla niego obcy. Wychowanie w takiej sytuacji nie jest działalnością zintegrowaną, lecz trafia do wychowanka bardziej jako efekt uboczny. Proces wychowania nie jest ukierunkowany na wychowanka, ale na realizację celu, którego wychowanek nie rozpoznaje i z którym się nie utożsamia. Podejmowane aktywności, z którymi wychowawca się nie utożsamia, kompromitują go jako specjalistę oraz podają w wątpliwość jego działalność. Brak zgodności w procesie wychowania skutkuje wyobcowaniem jego podmiotów. Filek utożsamia wychowanie wyobcowane z instrumentalizacją wychowanka. Scedowanie tego zadania na podmiot pośredni (reorientacja działalności wychowawczej) może być przykładem dezintegracji celów wychowawczych.

Pseudowychowaniem jest także zawładanie. Ma ono miejsce wówczas gdy różnice pomiędzy podmiotami z czasem utrwalają się na tyle, że przyjmują postać panowania człowieka nad człowiekiem. Dawne metody wychowawcze opierały się w dużej mierze na panowaniu wychowawcy nad wychowankiem, współcześnie zaś można mówić o partnerstwie w wychowywaniu. Należy stanowczo stwierdzić, że takie ujęcie zaprzecza wychowaniu, koresponduje natomiast z przymusem jako formą oddziaływania zewnętrznego. Należy stanowczo stwierdzić, że władza/ujarzmianie budzi sprzeciw zarówno wychowanka, jak i dorosłego. Dość powszechna wydaje się forma buntu/strajku jako próba uwolnienia się spod jarzma oddziaływania pedagogicznego. O ile w przypadku wychowanka można je tłumaczyć próbą zniesienia wspomnianej hegemonii, o tyle zachowanie takie u podmiotu pośredniego jest niedopuszczalne. Powstaje bowiem pytanie: kto dla kogo jest dziś autorytetem w kwestii wychowania? Trudno nie odnieść wrażenia, że to podmioty pośrednie uzurpują sobie prawo do bycia autorytetami $\mathrm{w}$ tej dziedzinie, a potwierdzeniem tej tezy jest ich dążenie do utrzymania 
się przy władzy. Ich bezwzględność nie ma jednak nic wspólnego ani z troską o losy wychowanka, ani z samym wychowaniem. Taka działalność, która wymyka się spod panowania, jest zarzewiem konfliktu. Wychowawca, który nie godzi się na to, by ujarzmiać innych, naraża się na to, że on sam będzie niesprawiedliwie traktowany.

Według Jacka Filka wielkość wychowawcy można rozpoznać w jego krzywdzie. Gdy nie traci on z oczu personalnego charakteru wychowania, próbuje go bronić przed instytucjonalizacją i pseudo-działalnością pedagogiczną, naraża się na gnębienie. Odpowiedź na nie objawia się w charyzmacie, dzięki któremu wychowawca ma szansę zachować autonomiczność. Gdy ma on inny pomysł na wychowanie i potrafi do niego pociągnąć młodych, jest charyzmatykiem. Obranie przez niego takiego sposobu myślenia o wychowaniu, jakie proponuje Filek, stanowi zagrożenie dla standardowej działalności pedagogicznej. Na ogół charyzmat wymyka się kontroli i stanowi zagrożenie dla panujących. Podobnie dzieje się w przestrzeni wychowania. Rodzicom jako zbiorowemu podmiotowi bezpośredniemu przynależy pierwszeństwo w tej kwestii i decydowanie o tym, jak dziecko wychować. Za pośrednictwem podmiotów pośrednich takich jak instytucje pomocowe, profilaktyczne i oświatowe próbuje się ich w tym wyręczyć, zastąpić, po to aby zwiększyć możliwość oddziaływania tych organizacji. Zdezorientowani rodzice niekiedy wolą złożyć broń, niż zawalczyć o to, co w gruncie rzeczy należy do ich niezbywalnych praw - o wychowanie własnych dzieci. Są też oczywiście i tacy, którym zdanie swoich obowiązków na podmioty pośrednie wystarcza. Zadowolą się oni pozornym zaangażowaniem w kwestie okołowychowawcze, symulowaniem działania. W konsekwencji wychowankowie będą udawać, że są wychowywani. Wydaje się, że wychowanie zawładające jest dla rodziców - podmiotów bezpośrednich - najdotkliwszą formą zdecentralizowania ich wypływów wobec własnych dzieci.

\subsection{Celowość wychowania}

Wychowanie wyłania się jako nieautentyczne, przeciwstawne temu prawdziwemu, gdy jest dookreślane przyimkami „do”, czy „na”. Tego rodzaju sformułowania ukazują tylko wycinek wychowania (jego przedmiotowość), nie zaś jego całościowy sens. Przypisywanie wychowaniu celów stanowi 
zagrożenie dla poprawności terminologicznej. Wychowanie jako działanie mające zapisane w swej specyfice cel bywa dookreślane poprzez przypisywanie definicji kolejnych celów. Wydaje się więc słusznym stworzenie takiego opisu celów wychowania, który by nie rozbudowywał definicji, ale ją porządkował. J. Filek cele wychowania rozróżnia na cele immanentne i transcendentne. Takie działanie które odróżnia je spośród innych oddziaływaniem wychowawczym będzie celem immanentnym wychowania. Można powiedzieć, że ten cel wychowania jest doświadczany przez podmiot doznający działania jako pierwszy. Dzięki niemu podmiot wychowania może wyróżnić swój status, czyli że jest na przykład wychowankiem, bo wychowawca go wychowuje. Całą działalność towarzyszącą temu celowi głównemu można zawrzeć w celach transcendentnych. J. Filek przekonuje, że: „immanentny wychowaniu cel jest nie tyle celem wychowania, ile celem działalności, która dzięki tej właśnie, a nie innej celowości jest wychowaniem"15. Ilekroć do celu immanentnego (zinterioryzowanego), będą przypisywane transcendentne cele (zewnętrzne), działalność wychowawcza będzie służyła wpierw jako środek do realizacji tych celów, a więc zostanie w pewien sposób zinstrumentalizowana. Takie podejście, w odczuciu J. Filka, nie godzi się z podmiotowym stosunkiem do samej działalności wychowawcy, a przez to - do samego wychowanka. Wychowanie w jakimś celu, będzie zatem przysposabiało wychowanka do czegoś. Nie można jednak pomijać absolutnego istnienia osoby ludzkiej - wychowanka nie można przypisać do czegoś, jest on celem samym w sobie. $Z$ uwagi na różnorakie uwarunkowania społeczne i polityczne, trzeba stanowczo stwierdzić, że wychowanie jest już zadaniem samym w sobie. Zachowując autonomiczność nie będzie podlegać dezorientacjom definicyjnym.

\section{Podsumowanie}

Zdemaskowane przez Filka cztery odsłony pseudowychowania: wychowanie nieadekwatne, fikcyjne, wyobcowane i zawładające/ujarzmiające nie wyczerpują tego pola badań. Otwierają natomiast drzwi do wychowania w przestrzeni autentycznej. Takie podejście opiera się na wzajemności

15 J. Filek, Filozofia jako etyka. Eseje filozoficzno-etyczne, dz. cyt., s. 113. 
oddziaływania i doznawania. Początkowo wychowanie nie znosi naturalnie powstałej nierówności pomiędzy podmiotami. Prawdziwy wychowawca jednak tak prowadzi ten proces, aby on sam jako podmiot wychowujący stał się zbędny. Wychowanek podejmuje się wówczas trudu samowychowania. Wola wychowawcy skupia się więc bardziej na uwolnieniu samoodpowiedzialności u wychowanka niż na jej postępowym kształtowaniu. Filek zaprzecza możliwości wychowania człowieka przez człowieka. Twierdzi, że w gruncie rzeczy wychowanie jest zadaniem każdego z osobna. Nikt inny za nas samych wykonać tego nie może ${ }^{16}$. Filozof stwierdza: „Przeto praca człowieka nad człowiekiem, jaką jest wychowanie, może mieć tylko jeden materialnie określony cel: podprowadzenie wychowywanego ku miejscu, w którym będzie on już zdolny podjąć samodzielnie pracę nad sobą, krótko mówiąc, uczynienie go zdolnym do samowychowania"17. Wychowawca towarzyszy wychowankowi w tym procesie w sposób subtelny, a jednocześnie na tyle skuteczny, że wychowanek przejmuje się swoim wychowaniem. Miejscami, w których wychowanek podejmuje akcję samowychowawczą, są codzienne - banalne i powtarzalne - wybory, ale także sytuacje trudne, nieoczywiste i jednostkowe. Podjęcie trudu samowychowania odbywa się w sposób naturalny i dobrowolny.

Wychowanie jest niewątpliwie jedną z tych kategorii, które służą lepszemu zrozumieniu rzeczywistości, w jakiej żyje rodzina. Wychowanie to nieustająca praca człowieka nad człowiekiem, a bardziej precyzyjnie - wobec drugiego człowieka w ciągu życia. Wychowanie nie jest zadaniem zarezerwowanym tylko wobec dzieci. Jest bardziej dialogicznym stosunkiem ludzi wobec siebie, związanym z przeżywaniem konkretnych wartości. Wychowanie nie wydarza się w jakimś ściśle określonym momencie i nie w samotności, lecz jest procesem, dzięki któremu możliwe staje się zawiązanie więzi z drugim człowiekiem. Zdaniem Magdaleny Kapias - autorki prac z zakresu filozofii wychowania i zagadnień dotyczących domu i wspólnoty rodzinnej - „zawiązanie się relacji i tworzenie więzi między stronami wychowania wymaga ciągłego obdarowywania się czasem w tym znaczeniu, że czas

\footnotetext{
16 Por. J. Tischner, Alfabet duszy i ciała, dz. cyt., s. 231.

17 J. Tischner, Alfabet duszy i ciała, dz. cyt., s. 118.
} 
jest warunkiem koniecznym do realizacji swojego powołania w obszarze wychowania"18.

Obecność wyraża się w zaangażowanym uczestnictwie w procesie wychowania. Brak czasu i brak pomysłu na wychowywanie stanowią powszechną próbę usprawiedliwienia niedopełnienia obowiązków wychowawców. Natura dziecka jest powołana do wychowania, które oczywiście będzie wiązało się $\mathrm{w}$ pewnym stopniu $\mathrm{z}$ dyrektywnym kierowaniem, ale uszanuje dziecięcą wrażliwość. Liczenie na to, że dziecko samodzielnie pokona ten odcinek wychowania, który uzdolni je do właściwego pojmowania i urzeczywistniania wartości we własnym życiu, stanowi przeniesienie punktów odpowiedzialności z wychowawcy na wychowanka. Jarosław Gara dostrzega zagrożenie w niewypracowaniu kanonu wychowania. Badacz wyraża przekonanie, że wychowanek musi działać „w oparciu o coś, co będzie się odwoływało do jego możliwości, potencjalności, optymalnego funkcjonowania i wrastania w miarę swego ukrytego w zalążku człowieczeństwa"19.

Przed wychowawcą, któremu wydaje się, że oto będzie wychowywać, ukazuje się równolegle zadanie - zmierzenia się przede wszystkim z własnym wychowaniem. Prawda o wychowaniu umacnia się w przestrzeni aksjologicznej. Wychowawca odsłania przed wychowankiem znaczenie spotkania i dialogu. Tadeusz Gadacz wskazuje na znaczenie prawd dla wychowania. Pisze: „istnieją prawdy, których można nauczyć się z książki, do których można dojść przez intelektualne spekulacje. Lecz są takie prawdy, na które nie ma teoretycznej odpowiedzi. Można je poznać jedynie poprzez osobiste świadectwo i własne życiowe ich doświadczenie"20. Wychowanie jest doświadczeniem przejmującym, nie tylko dlatego, że czyni człowieka odpowiedzialnym za jego własny los. Samowychowanie uzdalnia człowieka do spotkania ${ }^{21}$ i nawiązania dialogu ze światem wartości.

18 M. Kapias, Rozważania nad istotą wychowania, „Świdnickie Studia Teologiczne” 14 (2017) nr 2, s. 75.

19 J. Gara, Człowiek i wychowanie, dz. cyt., s. 112.

20 T. Gadacz, Wychowanie jako spotkanie, w: Wychowanie osobowe, red. F. Adamski, Kraków 2011, s. 95-96.

21 Zob. M. Jagiełło, Spotkania, które zmieniają. O spotkaniu jako kategorii pedagogicznej i wydarzeniu wychowującym na drodze życia, Kraków 2012. 


\section{Bibliografia}

Gadacz T., Wychowanie jako spotkanie osób, w: Wychowanie osobowe, red. F. Adamski, Kraków 2011, s. 87-96.

Gara J., Człowiek $i$ wychowanie. Implikacje pedagogiczne antropologii filozoficznej Maxa Schelera oraz analogie z wybranymi koncepcjami psychologicznymi, Warszawa 2007.

Gara J., Od filozoficznych podstaw wychowania do ejdetycznej filozofii wychowania, Warszawa 2009.

Jagiełło M., Spotkania, które zmieniają. O spotkaniu jako kategorii pedagogicznej i wydarzeniu wychowującym na drodze życia, Kraków 2012.

Filek J., Fenomenologia wychowania. Wprowadzenie, w: J. Filek, Filozofia jako etyka. Eseje filozoficzno-etyczne, Kraków 2001, s. 82-120.

Kapias M., Rozważania nad istotą wychowania, „Świdnickie Studia Teologiczne" 14 (2017), nr 2, s. 67-76.

Kapias M., Szkoła rodzinna jako alternatywna kategoria wychowawcza, w: Opieka jako kategoria wychowawcza. Metody i formy stymulowania dzieci i młodzieży w rodzinie i środowisku lokalnym, red. U. Gruca-Miąsik, Rzeszów 2016, s. 62-69.

Kondycja edukacji domowej w Polsce, www.edukacjadomowa.pl/kondycja-edukacji-domowej-w-polsce/ (23.07.2018).

Maj A., Wychowanie, w: Encyklopedia aksjologii pedagogicznej, red. K. Chałas, A. Maj, Radom 2016, s. 1368-1380.

Skarga B., Kwintet metafizyczny, Kraków 2005.

Tischner J., Alfabet duszy i ciała, Kraków 2018.

Tischner J., Filozofia dramatu. Wprowadzenie, Paryż 1990 (I wydanie krajowe: Kraków 1998), (Znaki czasu, 55),

Tischner J., Droga Sokratesa i perć Sabały, www.tischner.pl/aktualnosc/1365/ 1/ks-jozef-tischner-droga-sokratesa-i-perc-sabaly (15.11.2016).

Walczak P., Wychowanie jako spotkanie. Józefa Tischnera filozofia człowieka jako źródło inspiracji pedagogicznych, Kraków 2009. 